PENGKAJIAN

\title{
PENENTUAN BESARAN BATASAN (THRESHOLD) TERHADAP \\ PERUNTUKAN KEGIATAN PERUMAHAN WAJIB ANDALALIN
}

\author{
Dr. Effendhi Prih Raharjo, ST, MT \\ Dosen STTD \\ J1. Raya Setu No. 89 Cibuntu, \\ Cibitung Bekasi 17001 \\ Telp/Fax. 0218254640 \\ peffendi@yahoo.com \\ Dani Hardiyanto, S.SiT, M.Sc \\ Dosen STTD \\ J1. Raya Setu No. 89 Cibuntu, \\ Cibitung Bekasi 17001 \\ Telp/Fax. 0218254640
}

\author{
Azrisal, A.TD, MM \\ Dosen STTD \\ J1. Raya Setu No. 89 Cibuntu, \\ Cibitung Bekasi 17001 \\ Telp/Fax. 0218254640 \\ Sahar Andika, SH, MH \\ Dosen STTD \\ J1. Raya Setu No. 89 Cibuntu, \\ Cibitung Bekasi 17001 \\ Telp/Fax. 0218254640
}

\begin{abstract}
Supporting regulations are less able to describe in detail the limits of liability (threshold) to Traffic Impact Analysis. There should be a definite guidelines to avoid differences in the views of developers regarding the mandatory criteria Traffic Impact Analysis in each area. This study aims to get the criteria in determining the location of mandatory limits on the amounts and purposes Traffic Impact Analysis construction or development of land use.

The results showed that every construction / development of land use that can increase the volume of traffic up to $10 \%$ of the volume of the previous require traffic impact analysis.

Comparative analysis of traffic volume and land use area to determine the magnitude of the effect of land use area to trip generation or traffic volume. Trip generation on the land use area of more than or equal to $165 \mathrm{~m}^{2}$ Traffic Impact Analysis mandatory.

The number of units of the building will affect the amount of trip generation and traffic volume to value ratio of the volume of traffic and trip generation of the number of building units is greater than or equal to 77 units are required to do Traffic Impact Analysis.
\end{abstract}

Keywords: Limitation Traffic Impact Analysis, Trip Generation, Land Use Area and Total Units.

\begin{abstract}
ABSTRAKSI
Peraturan pendukung yang kurang dapat menjelaskan secara rinci mengenai batasan-bataasan kewajiban (threshold) terhadap Andalalin. Seharusnya ada pedoman yang pasti untuk menghindari perbedaan pandangan para pengembang mengenai kriteria wajib andalalin di setiap daerah. Penelitian ini bertujuan untuk mendapatkan kriteria dalam menentukan batasan lokasi wajib andalalin terhadap besaran dan peruntukan pembangunan atau pengembangan guna lahan.

Hasil penelitian ini menunjukkan bahwa setiap pembangunan/pengembangan guna lahan yang dapat meningkatkan volume lalu lintas sampai dengan $10 \%$ dari volume sebelumya memerlukan analisis dampak lalu lintas.

Analisis perbandingan volume lalu lintas dan luasan lahan untuk mengetahui besaran pengaruh luasan lahan terhadap bangkitan perjalanan atau volume lalu lintas. Bangkitan perjalanan pada luasan lahan lebih dari atau sama dengan $165 \mathrm{~m}^{2}$ wajib dilakukan andalalin. Jumlah unit bangunan akan mempengaruhi besarnya bangkitan perjalanan dan volume lalu lintas, untuk nilai perbandingan volume lalu lintas dan bangkitan perjalanan terhadap jumlah unit bangunan adalah lebih dari atau sama dengan 77 unit wajib untuk dilakukan andalalin.
\end{abstract}

Kata Kunci : Batasan Andalalin, Bangkitan Perjalanan, Luas Lahan dan Jumlah Unit 


\section{PENDAHULUAN}

Kewajiban melakukan analisis dampak lalu lintas bagi pengembang dalam mengembangankan kegiatan yang berupa perubahan tata guna lahan sudah lazim dilakukan akhir-akhir ini. Hal ini selaras dengan amanah Undang-Undang No. 22 Tahun 2009 yang mewajibkan dalam setiap rencana pembangunan pusat kegiatan, permukiman, dan infrastruktur yang akan menimbulkan gangguan Keamanan, Keselamatan, Ketertiban, dan Kelancaran Lalu Lintas dan Angkutan Jalan wajib dilakukan analisis dampak Lalu Lintas. Disisi lain permasalahan muncul karena kurangnya peraturan pendukung dalam menjelaskan secara rinci yang berupa Permen (PM) terutama berkaitan dengan batasanbatasan wajib andalalin yang harus dipedomani. Masalah lain yang dihadapi oleh Indonesia saat ini adalah belum adanya batasan (threshold) untuk analisis dampak lalu lintas. Seharusnya, tidak semua pengembangan harus melakukan kajian analisis dampak lalu lintas, khususnya bagi pengembangan yang berskala kecil. Permasalahan definisi skala kecil perlu ditetapkan. Sedangkan skala yang sangat besar merupakan kota di dalam kota, mungkin harus dilakukan suatu studi makro terlebih dahulu (perencanaan transportasi kota) sebelum masuk ke kajian analisis lalu lintas untuk unit-unit bangunan di dalamnya (Cahyono,2010).

\section{TINJAUAN PUSTAKA}

Beberapa penelitian berkaitan dengan batasan wajib analisis dampak lalu lintas dapat dilihat dari:

1. Standar Batasan di Inggris (Institution of Highway and Transportation, 1993)

Studi analisis dampak lalu lintas patut dilaksanakan apabila:

a. Lalu lintas yang dibangkitkan/ditarik dari suatu pembangunan kawasan melebihi $10 \%$ dari volume lalu lintas yang ada di jalan yang berdampingan;

b. Kemacetan lalu lintas telah terjadi atau akan terjadi dan lalu lintas yang dibangkitkan pembangunan kawasan melebihi $5 \%$ dari arus lalu lintas yang ada di jalan yang berdampingan.

Tabel I Standar Batasan di Inggris

\begin{tabular}{cc}
\hline Peruntukan lahan & Ukuran minimal kawasan yang wajib andalalin \\
\hline Perumahan & Lebih dari 200 unit \\
Bisnis/Perkantoran & Ground Floor Areas (GFA) lebih dari $7000 \mathrm{~m}^{2}$ \\
Pergudangan & GFA lebih dari $7500 \mathrm{~m}^{2}$ \\
Pertokoan & GFA lebih dari $1000 \mathrm{~m}^{2}$ \\
\hline
\end{tabular}


2. Juknis Andalalin Dirjen Perhubungan Darat Tahun 1995

Dalam SK Dirjen tersebut ditetapkan batasan yang mewajibkan analisis dampak lalu lintas, batasan-batasan tersebut dapat dilihat pada tabel berikut:

Tabel II Batasan-batasan Wajib Andalalin Sesuai Dengan Juknis Andalalin Dirjen Perhubungan Darat Tahun 1995

\begin{tabular}{cc}
\hline Peruntukan lahan & $\begin{array}{c}\text { Ukuran minimal kawasan yang } \\
\text { wajib andalalin }\end{array}$ \\
\hline Pemukiman & 50 unit \\
Apartemen & 50 unit \\
Perkantoran & $1.000 \mathrm{~m}^{2}$ luas lt bangunan \\
Pusat perbelanjaan & $500 \mathrm{~m}^{2}$ luas lt bangunan \\
Hotel/motel/penginapan & 50 kamar \\
Rumah sakit & 50 tempat tidur \\
Klinik bersama & 10 ruang praktek dokter \\
Sekolah/universitas & 500 siswa \\
Tempat kursus & 50 siswa / waktu \\
\hline
\end{tabular}

3. Kriteria yang digunakan sebagai Indikator dalam penentuan batasan Wajib Analisis Dampak lalu Lintas

Penentuan kriteria batasan dilakukan dengan menggunakan standar yang ada dan berlaku di Indonesia serta disesuaikan dengan karakteristik lalu lintas yang umumnya ada di Indonesia. Kemudian dengan hipotesis sementara ditambahkan sebagai kriteria sementara yang nantinya digunakan sebagai acuan penelitian. Berikut keriteria yang harus digunakan:

a. Berdasarkan (Institution of Highway and Transportation, 1993)

Studi analisis dampak lalu lintas patut dilaksanakan apabila:

1) Lalu lintas yang dibangkitkan/ditarik dari suatu pembangunan kawasan melebihi $10 \%$ dari volume lalu lintas yang ada di jalan yang berdampingan;

2) Kemacetan lalu lintas telah terjadi atau akan terjadi dan lalu lintas yang dibangkitkan pembangunan kawasan melebihi $5 \%$ dari arus lalu lintas yang ada di jalan yang berdampingan.

b. Selain lokasi kawasan khusus yang merupakan kawasan demand management seperti Tree in One, pembatasan kendaraan, kawasan tertib lalu lintas (wajib dilakukan andalalin) 
Pada Lokasi simpang daerah yang mempunyai V/C ratio diatas 0,8 wajib dilakukan analisis dampak lalu lintas. Karena pada dasarnya tujuan pelaksanaan kajian andalalin adalah untuk meminimalisir konflik yang mungkin ada dan mempertahankan kinerja lalu lintas pada saat ini.

\section{Hubungan antara Tarikan Perjalanan, Luas Bangunan, Jumlah Tenaga Kerja} dan Jenis Pelayanan Berdasarkan Lokasi serta Volume Lalu Lintas

Hubungan yang ingin diketahui menggunakan pendekatan statistik, dengan melakukan pemodelan untuk masing-masing variabel bebas (Luas Bangunan, Jumlah Tenaga Kerja, Jenis Pelayanan dan Lokasi).

a. Model tarikan perjalanan.

Black (1981), menyatakan bahwa model regresi linier adalah suatu model statistik untuk mengetahui bagaimana suatu variabel tidak bebas (Y) yaitu perjalanan dipengaruhi oleh variabel bebas (X). Setelah variabel tidak bebas dan variabel bebas telah ditentukan maka perlu diketahui hubungan antar variabel yang ada, hal ini untuk menentukan variabel mana yang akan dipakai. Jika terdapat variabel $\mathrm{X}$ tidak kuat hubungannya dengan varibel $\mathrm{Y}$, maka variabel tersebut tidak digunakan dan jika antar variabel X memiliki hubungan kuat / berkorelasi tinggi dengan variabel $\mathrm{X}$ lainnya, maka salah satu saja variabel $\mathrm{X}$ yang digunakan.

Persamaan regresi linier secara umum, sebagai berikut :

$$
\mathrm{Y}=\mathrm{a}+\mathrm{b} 1 \mathrm{X} 1
$$

Sumber : Harinaldi, 2005

Dengan :

a $\quad=$ Konstanta

b1 $\quad=$ Koefisien regresi

$\mathrm{Y} \quad=$ Variabel tidak bebas

$\mathrm{X} 1 \quad=$ Variabel bebas

Analisis regresi linier harus menetukan terlebih dahulu korelasi antar variabel.

Dalam melihat hubungan korelasi antar variabel, dengan melihat besaran nilai koefisien korelasinya ( $\mathrm{r}$ ).

b. Koefisien Determinasi $\left(\boldsymbol{R}^{2}\right)$

Penggunaan nilai $\mathrm{R}^{2}$ sangat banyak digunakan dalam mengukur ketepatan suatu model, akan tetapi nilai ini juga memiliki predikat pengukuran 
model yang lemah. $\mathrm{R}^{2}$ juga memberi bobot yang terlalu besar untuk nilai kesalahan mutlak yang besar dan nilai $\mathrm{R}^{2}$ yang tinggi tidak dapat diperoleh dari suatu pasangan data dengan nilai kesalahan yang kecil dan jumlah sel yang besar, tetapi mempunyai hubungan yang kurang kuat pada nilai sel yang kecil. Semakin besar $\mathrm{R}^{2}$, berarti hasil estimasi yang diperoleh dari model semakin mendekati data lapangan.

Peneliti menggunakan Adjusted $R$ Square dalam menguji koefisien determinasinya. Interpretasinya sama dengan $R$ Square, akan tetapi nilai Adjusted $R$ Square dapat naik atau turun dengan adanya penambahan variabel baru, tergantung dari korelasi antara variabel bebas tambahan tersebut dengan variabel terikatnya. Nilai Adjusted $R$ Square dapat bernilai negatif, sehingga jika nilainya negatif, maka nilai tersebut dianggap 0 , atau variabel bebas sama sekali tidak mampu menjelaskan varians dari variabel terikatnya dan tidak dapat dilakukan ke tahap uji lainnya seperti Uji $t$ dan Uji $F$. Adapun bentuk umum dari Adjusted $R$ Square dapat dilihat pada persamaan (3):

$$
\mathrm{R}^{2}=1-\left(1-\mathrm{R}^{2}\right) \frac{(N-1)}{(N-k-1)}
$$

Sumber : Spyros et al, 1983

Dimana:

$$
\begin{aligned}
\mathrm{R}^{2} & =\text { Koefisien Determinasi } \\
\mathrm{N} & =\text { Jumlah data } \\
\mathrm{K} & =\text { Jumlah variabel bebas } \\
(\mathrm{N}-\mathrm{k} & -1) \text { merupakan kesalahan derajat bebas (kesalahan } \mathrm{df})
\end{aligned}
$$

\section{Uji Linieritas}

Pemodelan yang digunakan dalam membangun model akan dilihat bentuk regresinya, apakah linier atau non-linier. Uji statistik yang digunakan untuk melihat apakah model tersebut linier atau tidak, dapat diketahui secara visual melalui diagram scatter. Selain secara visual dapat juga diketahui dengan melihat nilai-nilainya, untuk mengetahui apakah linier atau tidak dapat dilihat parameter Linearity dan Deviation From Linearity / sebarapa jauh simpangan hubungan variabel, kedua parameter tersebut dapat dilihat pada tabel ANOVA, untuk di SPSS terletak pada uji Compare Means. Dengan ketentuan jika signifikansi pada nilai linearitynya $(\mathrm{p}<0,05)$ hubungan variabel berbentuk linier, sedangkan untuk deviation from linearity nilai $(p>0,05)$ berarti simpangan 
terhadap linearitas tidak signifikan atau linier murni (tidak memiliki 2 bentuk, linier dan kuadratik / non-linier).

c. Uji Koefisien Model

Spyros et al, 1983 berpendapat bahwa Uji- $t$ terhadap koefisien individu adalah suatu uji tentang signifikansi bahwa koefisien $a$ dan $b$ sebagai variabel atau nilai pasangan $a$ dan $b$ berfluktuasi dari data satu ke data satu lainnya. Koefisien-koefisien individu dapat diberlakukan sebagai satu kesatuan yang dapat berdiri sendiri. Untuk persamaan Uji- $t$ dapat dilihat pada persamaan 4 .

$$
t \frac{b_{j}-\left(\beta_{j}\right)}{s e_{(b j)}}
$$

Sumber: Spyros et al, 1983

\section{Dimana :}

$\mathrm{b}_{\mathrm{j}} \quad=$ Koefisien $\mathrm{b}$ ke-j yang ditaksir, untuk menguji koefisien $a$ nilai huruf $b_{j}$ diganti dengan nilai koefisien $a$

$\beta_{\mathrm{j}} \quad=$ Parameter ke-j yang dihipotesakan

$\mathrm{se}_{(\mathrm{bj})}=$ Standar kesalahan $\mathrm{b}_{\mathrm{j}}$

Untuk melihat apakah benar ada hubungan kuat antara variabel $\mathrm{Y}$ dan $\mathrm{X}$ digunakan $U j i F$. Karena jika terjadi nilai koefisien $b=0,45$ (misalnya), maka masih ada kemungkinan kesalahan cukup besar atau menyatakan tidak ada hubungan antara $\mathrm{X}$ dan $\mathrm{Y}$, oleh karena itu dengan uji $\mathrm{F}$ dapat menjawab apakah model tersebut signifikan dapat digunakan atau ada hubungan antara $\mathrm{Y}$ dan $\mathrm{X}$. Dalam melakukan uji statistik dibantu dengan menggunakan perangkat lunak statistik SPSS. Untuk uji F dapat dilihat pada persamaan 5.

$$
\mathrm{F}=\frac{\left[R^{2} /(k)\right]}{\left[\left(1-R^{2}\right) /(\mathrm{N}-k-1)\right]}
$$

Sumber: Spyros et al, 1983

Dimana:

$R^{2} \quad=$ Koefisien Determinasi

$\mathrm{N} \quad=$ Jumlah data

$k=$ Jumalah variable bebas / regresor

( $\mathrm{N}-\mathrm{k}-1)$ merupakan kesalahan derajat bebas (kesalahan df)

\section{BAGAN ALIR PENELITIAN}

Penyusunan metodologi yang disampaikan dalam studi ini langsung ditekankan kepada tujuan utama untuk mengetahui sejauh mana Batasan Wajib analisis dampak dari 
Pembangunan pusat bangkitan terhadap lalu lintas di sekitar lokasi. Metodologi penelitian ini diharapkan mampu digunakan untuk memadukan seluruh proses penelitian secara umum. Metodologi penelitian yang disusun pada Kajian ini dapat dilihat pada diagram alir dibawah ini.

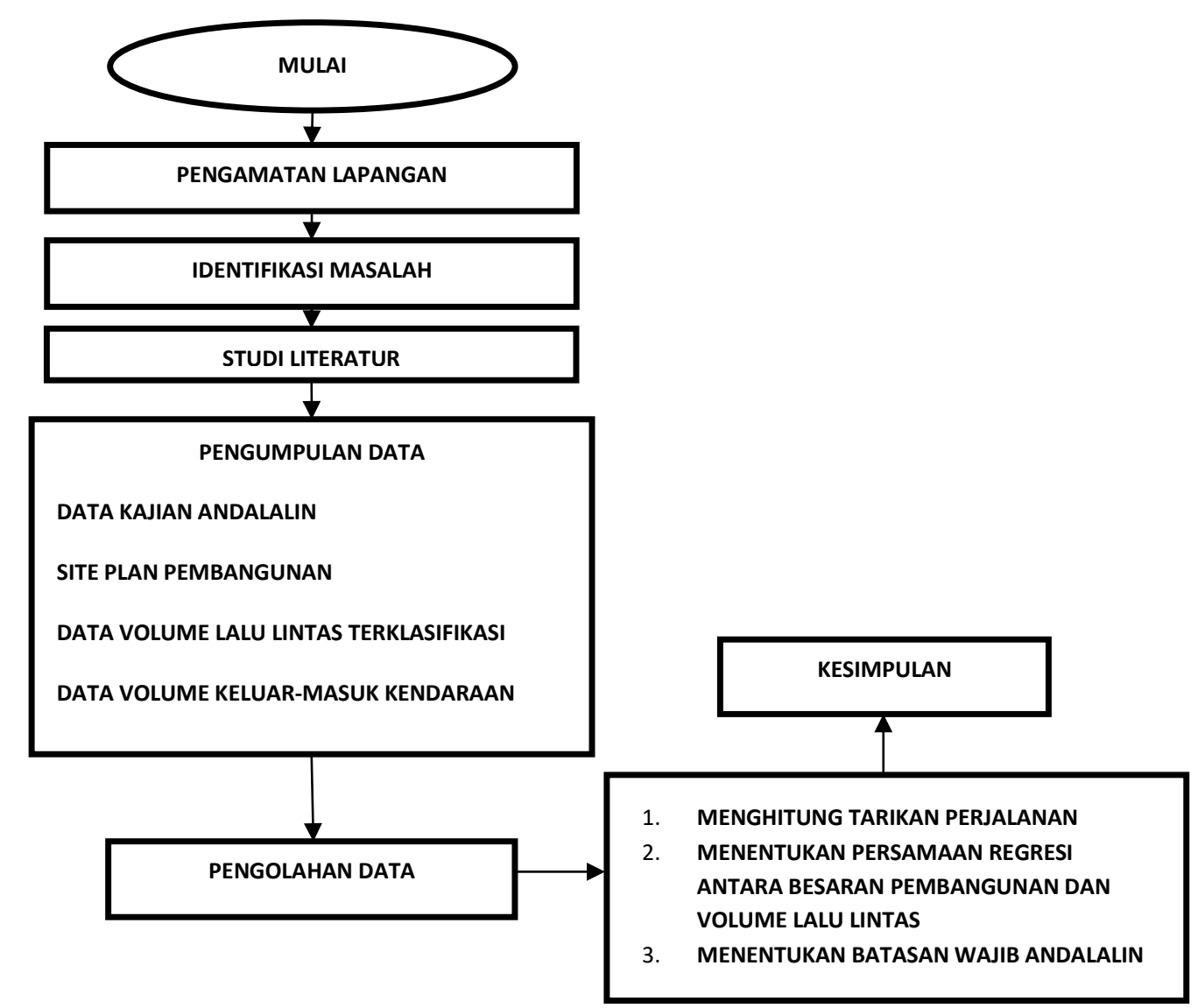

\section{ANALISIS DATA}

Berdasarkan data sekunder dan survai yang dilakukan, terdapat titik persebaran sesuai dengan jumlah pergerakan perjalanan baik itu membangkitkan maupun menarik terhadap pusat bangkitan. Berikut analisis data dari karakteristik perjalanan dari hasil studi maupun hasil survai tingkat bangkitan dan tarikan di wilayah Jabodetabek disesuaikan dengan peruntukannya. 


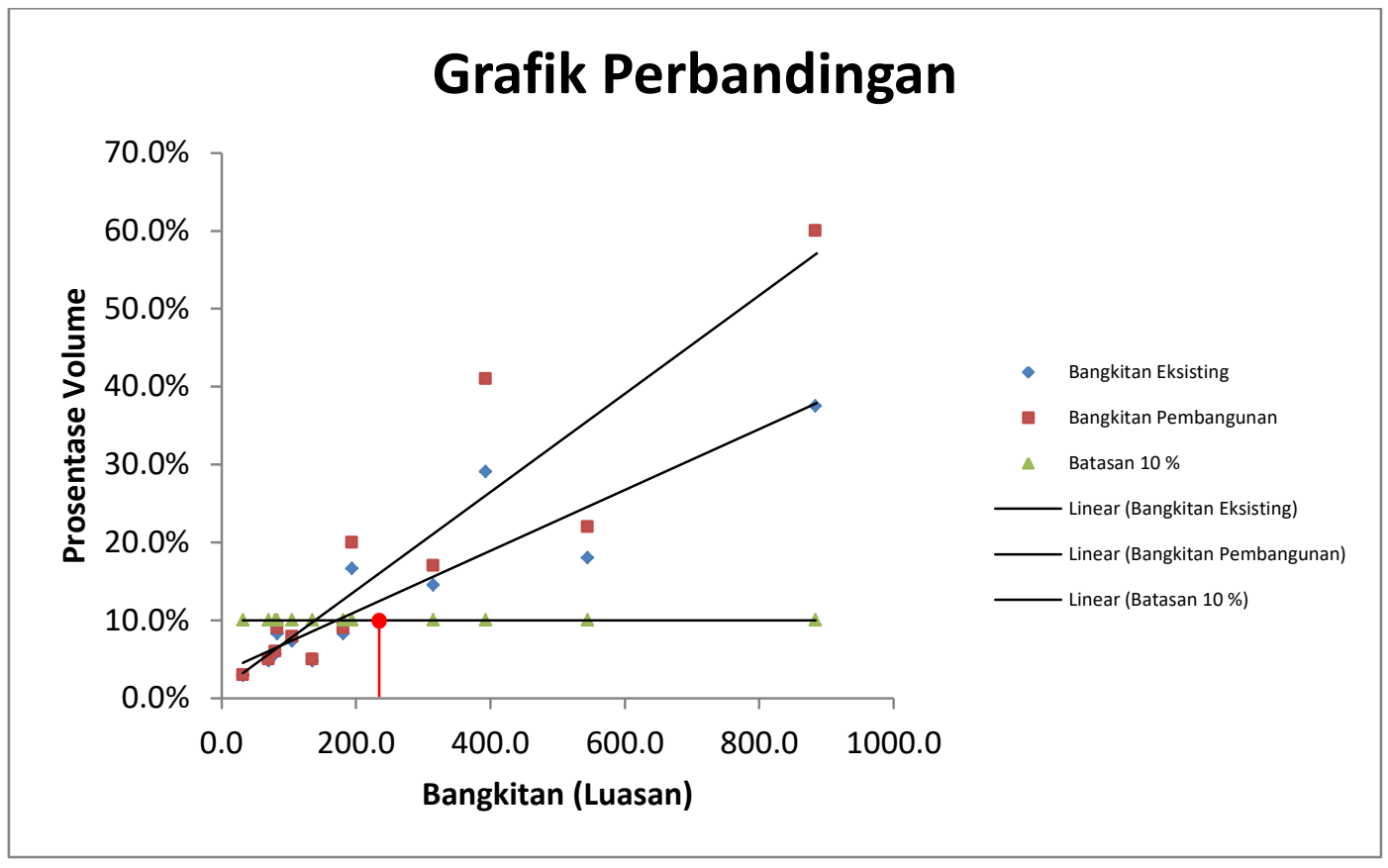

Gambar I Grafik Perbandingan Volume Lalu Lintas dan bangkitan terhadap luasan Lahan.

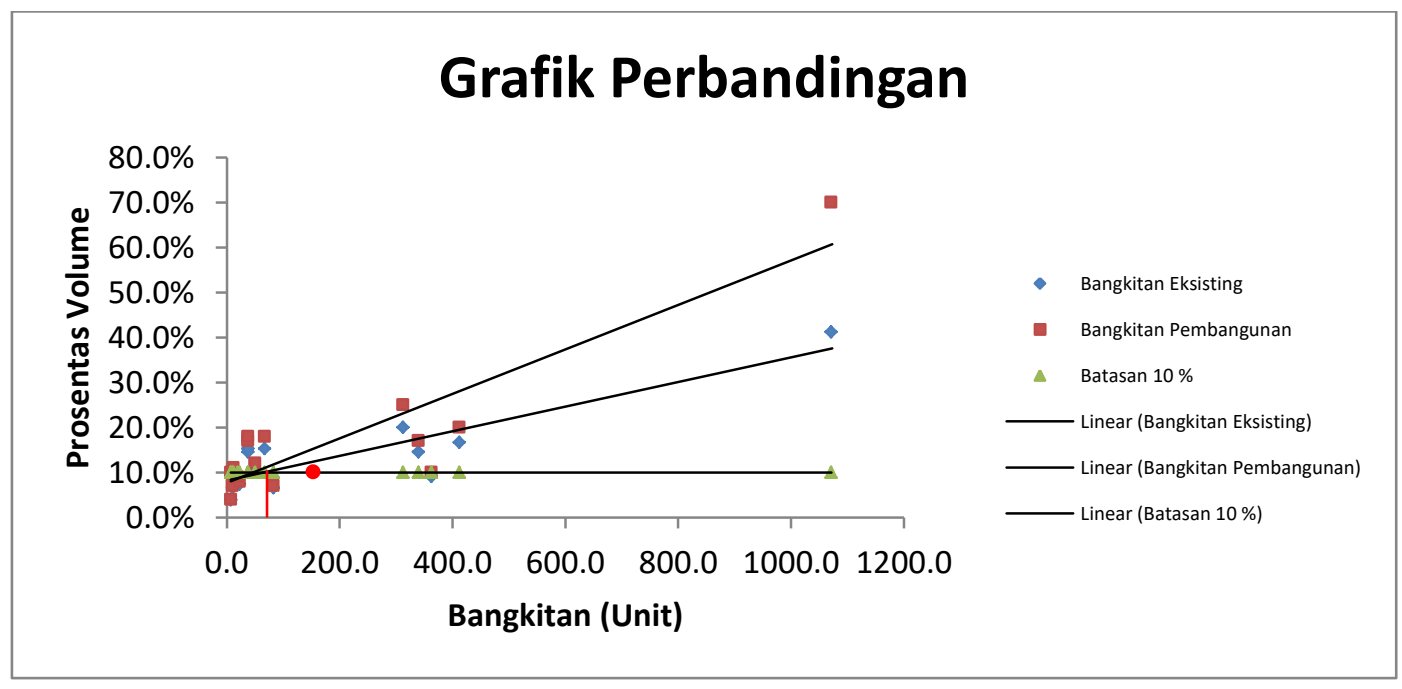

Gambar II Grafik Perbandingan Volume Lalu Lintas dan bangkitan terhadap jumlah Unit.

Dari grafik diatas menunjukan bahwasanya untuk setiap pembangunan melibatkan suatu luasan wilayah dan jumlah unit bangunan dengan batasan volume lalu lintas $10 \%$ dari volume lalu lintas sebelumya. Maka diwajibkan untuk setiap pembagunan atau pengembangan suatu wilayah untuk mendasarinya dengan Analisis Dampak Lalu Lintas. Untuk batasan $10 \%$ pada perbandingan volume lalu lintas dan bangkitan terhadap 
luasan lahan didapatkan bahwa lahan dengan luasan lebih dari sama dengan $165 \mathrm{~m}^{2}$ wajib dilakukan andalalin. Sedangkan untuk perbandingan volume lalu lintas dan bangkitan terhadap jumlah unit bangunan didapatkan bahwa jumlah unit bangunan lebih dari sama dengan 77 unit wajib untuk dilakukan andalalin.

\section{KESIMPULAN}

1. Berdasarkan hasil perhitungan analisa perbandingan volume lalu lintas dan luasan lahan diketahui luasan lahan mempengaruhi jumlah bangkitan dan volume lalu lintasnya. Luasan lahan kecil, akan berdampak pada jumlah bangkitan dan volume lalu lintas yang sedikit pula.

2. Berdasarkan dari analisa perbandingan volume lalu lintas dan jumlah unit bangunan diketahui jumlah unit mempengaruhi jumlah bangkitan dan volume lalu lintasnya. Jumlah bangunan sedikit, akan berdampak pada jumlah bangkitan dan volume lalu lintas yang sedikit pula.

3. Suatu Pembangunan perlu dilaksanakan andalalin bilamana volume lalu lintas hasil analisis setelah pembangunan selesai meningkat $10 \%$ dari volume lalu lintas sebelum dilakukan pembangunan.

4. Untuk batasan $10 \%$ pada perbandingan volume lalu lintas dan bangkitan terhadap luasan lahan didapatkan bahwa lahan dengan luasan lebih dari sama dengan $165 \mathrm{~m}^{2}$ wajib dilakukan andalalin.

5. untuk perbandingan volume lalu lintas dan bangkitan terhadap jumlah unit bangunan didapatkan bahwa jumlah unit bangunan lebih dari sama dengan 77 unit wajib untuk dilakukan andalalin.

6. Dalam Analisis Dampak Lalu Lintas baik untuk pembangunan dalam skala kecil, sedang dan besar tidak semata didasarkan pada jumlah unit bangunan dan luasan wilayah melainkan memperhitungkan bangkitan dan tarikan serta volume lalu lintas yang ditimbulkan pada masa yang akan datang. 


\section{DAFTAR PUSTAKA}

1. Anonim, Undang Undang Nomor 22 Tahun 2009 Tentang Lalulintas dan Angkutan Jalan, 2009, Jakarta.

2. Sugiyono, (2007), "Statistik Untuk Penelitian", Edisi kedua belas, Alfabeta, Bandung.

3. Tom V. Mathew dan K V Krishna Rao, 2006, "Introduction to Transportation Engineering",

4. Direktorat Jenderal Bina Marga Departemen Pekerjaan Umum, Manual Kapasitas Jalan Indonesia, 1997, Jakarta.

5. Wright, Paul H., Ashford, Norman J., Transportation Engineering : Planning and Design, Third Edition, 1989, John Wiley and Sons Inc., Canada

6. David A Hensher, Kenneth J Button. (2000). Handbook of Transport Modelling, Elsevier Science Ltd. United Kingdom.

7. F D Hobbs. (1979). Traffic Planning And Engineering, second edition, Pergamon Press, England.

8. Ortuzar J D, and Wilumsen L G.(1994). Modelling Transport, second edition, John Wiley \& Sons, Chichester, England.

9. Spyros et al. (1983). Metode dan Aplikasi Peramalan, Edisi Kedua diterjemahkan oleh Untung S Andriyanto dan Abdul Basith, Penerbit Erlangga, Jakarta.

10. Hadi S. (2004). Metodologi Research : Jilid 2, Edisi 2, Penerbit ANDI, Yogyakarta.

11. Harinaldi. (2005). Prinsi-Prinsip Statistik Untuk Teknik dan Sains. Penerbit Erlangga, Jakarta.

12. Ronald E Walpole, Raymond H Myers. (1995). Ilmu Peluang dan Statistika untuk Insinyur dan Ilmuan, Edisi Keempat, terjemahan RK. 